\title{
Body mass index have no effect in hospital mortality or intensive care outcomes in an inner city population
}

Sindhaghatta Venkatram ${ }^{1}$, Vimala Rapaka², Muhammad Anwer ${ }^{3}$ and Gilda Diaz-Fuentes ${ }^{4 *}$

*Correspondence: gfuentes@bronxleb.org

${ }^{1}$ Assistant Professor of Clinical Medicine at Albert Einstein College of Medicine, Division of Pulmonary and Critical Care Medicine, Bronx-Lebanon Hospital Center, Bronx, New York.

${ }^{2}$ Fellow in the Division of Pulmonary and Critical Care Medicine, Bronx-Lebanon Hospital Center, Bronx, New York.

${ }^{3}$ Fellow in the Division of Pulmonary and Critical Care Medicine, Bronx-Lebanon Hospital Center, Bronx, New York.

${ }^{4}$ Associate Professor of Clinical Medicine at Albert Einstein College of Medicine, Division of Pulmonary and Critical Care Medicine, Bronx-Lebanon Hospital Center, Bronx, New York.

\begin{abstract}
Background: The relationship between body mass index and outcome in the intensive care unit is controversial. The objective was to evaluate the incidence and effect of different body mass indexes on mortality, duration of mechanical ventilation, intensive care unit and hospital length of stay among critically ill medical patients.

Methods: Retrospective, single center study in a medical intensive care unit of an inner city teaching hospital. All patients with available BMI levels on admission were included.

Results: There were 1,988 patients admitted to the intensive care unit between January to December 2008; 1,797 (90.3\%) were analyzed. Based in body mass index, 162 (9\%) patients were underweight, 598 (33\%) normal, 774 (43\%) overweight/ obese and $263(14.6 \%)$ severe obesity. Patients with obesity/severe obesity were more likely to be female $(\mathrm{p}<0.0001)$; to have hypertension $(\mathrm{p}=<0.0001)$, diabetes mellitus $(\mathrm{p}=<0.0001)$ and obstructive sleep apnea $(\mathrm{p}=<0.0001)$ as comorbid conditions. Severely obese patients had lower APACHE IV scores ( $66 \pm 33$ vs. $71 \pm 32$, p=0.035) and higher like hood of mechanical ventilation $(105(40 \%)$ vs. $180(28 \%), \mathrm{p}=<0.0007)$ when compared to normal. Underweight patients were sicker (APACHE IV $80 \pm 32$ vs. $71 \pm 32, \mathrm{p}=0.002)$ and more likely to have HIV infection (55 (36.6\%) vs. $164(26 \%), \mathrm{p}=0.008)$ and cancer (22 vs. $51, \mathrm{p}=0.017)$ compared to normal. Neither underweight, obesity nor severe obesity were associated with an increased risk of hospital mortality, (odd ratio=1.162; 95\% confidence interval, $0.57-2.34$ for underweight, odd ratio $=1.04 ; 95 \%$ confidence interval, $0.62-1.75$ for overweight/obese, odd ratio=1.23; $95 \%$ confidence interval, $0.64-2.39$ for severe obesity). There were no differences in hospital length of stay or days on mechanical ventilation between the different body mass index groups. However, intensive care unit length of stay were significantly longer in the severe obese group by 1.2 days (95\% confidence interval, 1.00-1.09; $\mathrm{p}=0.0015)$ compared with all the other groups.

Conclusion: Body mass index in critically ill inner city patients is not associated with increased mortality. Severely obese patients have a longer intensive care unit length of stay, but not hospital stay. In our inner city MICU population, the prevalence of obesity and severe obesity is higher than reported.
\end{abstract}

Keywords: Intensive care unit, obesity, underweight, body mass index, mortality, length of stay, mechanical ventilation

\section{Background}

Obesity is a health epidemic of industrialized countries and has been associated with substantial morbidity and mortality in the general population. The 2010 National Health and Nutrition Examination Survey (NHANES) survey [1] shows that the prevalence of obesity in the United States has increased steadily in both men and women. The association of increased body mass index (BMI) with hypertension, diabetes mellitus, cardiovascular and pulmonary diseases and cancer is well reported [2-5]. At the other extreme, low BMI have been associated with higher mortality on patients with cardiovascular and peripheral vascular disease $[6,7]$. Population based studies suggest a $U$ or $J$ shaped curve indicating a higher mortality at the extremes of BMIs [8-10]. The association of BMI with mortality in the intensive care unit (ICU) is controversial with reports suggesting no relation [11-13], increased [14-16] or decreased hospital mortality [17]. The role of BMI for length of stay (LOS) on mechanical ventilation (MV) and ICU LOS is equally inconsistent [11,18-23].

There are no studies evaluating the effect of BMI in ICU outcomes in an inner city population. The prevalence of overweight and obesity in this population have been reported to be closer to $40 \%$, probably due their unique demographics. Additionally, inner cities have a higher rate of immigrants, uninsured and low income patients with a higher mortality rates from almost all diseases [24].

The effect of BMI on the outcome of this high risk group of patients who need intensive care admission is unknown. This study examines the prevalence of different categories of BMI in patients admitted to our inner city medical ICU and the association with hospital and ICU mortality.

\section{Materials and Methods Study design and setting}

This was a retrospective study conducted in a 26-bed

(C) 2013 Diaz-Fuentes et al; licensee Herbert Publications Ltd. This is an Open Access article distributed under the terms of Creative Commons Attribution License (http://creativecommons.org/licenses/by/3.0). This permits unrestricted use, distribution, and reproduction in any medium, provided the original work is properly cited. 
Venkatram et al. Internal Medicine Inside 2013,

closed adult medical ICU of a 970-bed hospital. Medical records of patients admitted to the unit between January and December 2008 were included.

\section{Methods}

All patients admitted to the ICU with available BMI levels on admission were included in the study. Exclusion criteria included: a) height or weight not available at the time of ICU admission and b) readmission to the ICU during the same hospital admission.

\section{Determination of BMI}

Height and weight data were routinely measured immediately on an admission to ICU. Body mass index, determined as weight $(\mathrm{kg}) /$ height $\left(\mathrm{m}^{2}\right)$, was calculated for all patients. As per ICU policy, BMI was validated if there was a difference of more or equal to $10 \%$ in subsequent measurements. Other validation measures included admission dietary assessment notes.

\section{Definition and classification of obesity}

The classification system of obesity by BMI developed by the World Health Organization Obesity Task Force and adopted by the Expert Panel on the Identification, Evaluation, and Treatment of Overweight and Obesity in Adults, of the National Heart, Lung, and Blood Institute of the National Institutes of Health was used $[\mathbf{2 5 , 2 6 ]}$. Based on BMI, patients were classified into five groups: underweight $(\mathrm{BMI} \leq 18.4$ $\mathrm{kg} / \mathrm{m}^{2}$ ); normal (18.5 to $24.9 \mathrm{~kg} / \mathrm{m}^{2}$ ); overweight ( 25 to 29.9 $\mathrm{kg} / \mathrm{m}^{2}$ ); obese (30 to $34.9 \mathrm{~kg} / \mathrm{m}^{2}$ and severely obese (BMI $\geq 35 \mathrm{~kg} / \mathrm{m}^{2}$ ). The overweight and obese categories were combined into one group for analysis.

Baseline demographics included age, gender and race, pre-existing conditions like hypertension (HTN), diabetes mellitus (DM), infection with Human immunodeficiency virus (HIV), end stage renal disease (ESRD)-defined as those patient undergoing dialysis, obstructive sleep apnea (OSA), cancer and history of tobacco, alcohol and substance use. Information was obtained from admission medical records. The acute physiology and chronic health evaluation (APACHE) IV score-derived risk of death during hospitalization was determined from the worst values obtained within 24 hours of ICU admission. Laboratory variables were obtained during the first 24 hours of admission to ICU and included hematocrit (HCT), serum creatinine, albumin, glutamic oxaloacetic transaminase (SGOT), glutamic pyruvic transaminase (SGPT), and international normalized ratio (INR). Right ventricular systolic pressure (RVSP) and ejection fraction (EF) from echocardiogram when available for that admission were obtained. Days on mechanical ventilator, ICU and hospital LOS, and mortality were abstracted from medical records. The primary outcome measure was hospital mortality. Secondary outcomes included requirement for mechanical ventilation and ventilator days, ICU and hospital LOS and tracheotomy rates. The study was approved by the hospital institutional research review board, and the need for informed consent was waived.

\section{Statistical analysis}

Data analysis was conducted using the Statistical Analysis System software 9.2 (SAS Institute, Cary, NC). Discrete variables are expressed as counts (percentage) and continuous variables as means \pm standard deviations (SD). For the demographic and clinical characteristics of the patients, differences between groups were assessed using the chi-squared test and Fisher's exact test for categorical variables; wilcoxon rank sum used for all continuous comparisons for data non-normally distributed; $p$ values listed for mean values across BMI categories were derived using analysis of variance (ANOVA). We determined which variables to include in the logistic regression model by looking for significant associations between these potential confounders and mortality (primary outcome) and primary independent variable BMI category. If there was a significant association in either assessment, we included that variable in the stepwise selection model in logistic regression. A p value less than 0.05 was considered statistically significant.

\section{Results}

Between January and December 2008, a total of 1,988 patients were admitted to the medical ICU, 191 patients were excluded due to either no BMl available or readmission to the ICU; 1,797 (90.3\%) patients were analyzed. The distribution of the BMI was as follows: $162(9 \%)$ patients were underweight, 598 (33\%) normal, 774 (43\%) overweight/ obese and 263 (14.6\%) severely obese (Figure 1). The mean BMl of the cohort was $27.5 \pm 8.5 \mathrm{~kg} / \mathrm{m}^{2}$ range $13.3-96.4 \mathrm{~kg} /$ $\mathrm{m}^{2}$. Distribution of BMls can be seen in Figure 2. Comparison of baseline characteristics for different BMI groups revealed that patients with obesity and severe obesity were more likely to be female, to have a lower APACHE IV score and to suffer from diabetes and hypertension. Patients in the underweight group were more likely to have HIV infection, malignancy and active use of tobacco, alcohol and recreational drugs. Anemia, hypoalbuminemia and low EF was also most commonly found in this group (Table 1). None of our patients had history of bariatric surgery or organ transplantation.

Data analysis revealed that neither underweight, overweight/obesity nor severe obesity were associated with an increased risk of hospital mortality compared to patients with normal BMI (Table 2). Analysis for secondary outcomes showed that patients with a non-normal BMI were more likely to require mechanical ventilation when compared to normal, $(p=0.006)$. No differences for ventilator days, tracheotomy rates and hospital LOS were found between the spectrums of BMIs. However, ICU LOS were significantly longer in the groups with higher compared to normal BMI (severe obesity $5.3 \pm 5.1$ and overweight/obesity $4.4 \pm 4.5$ 

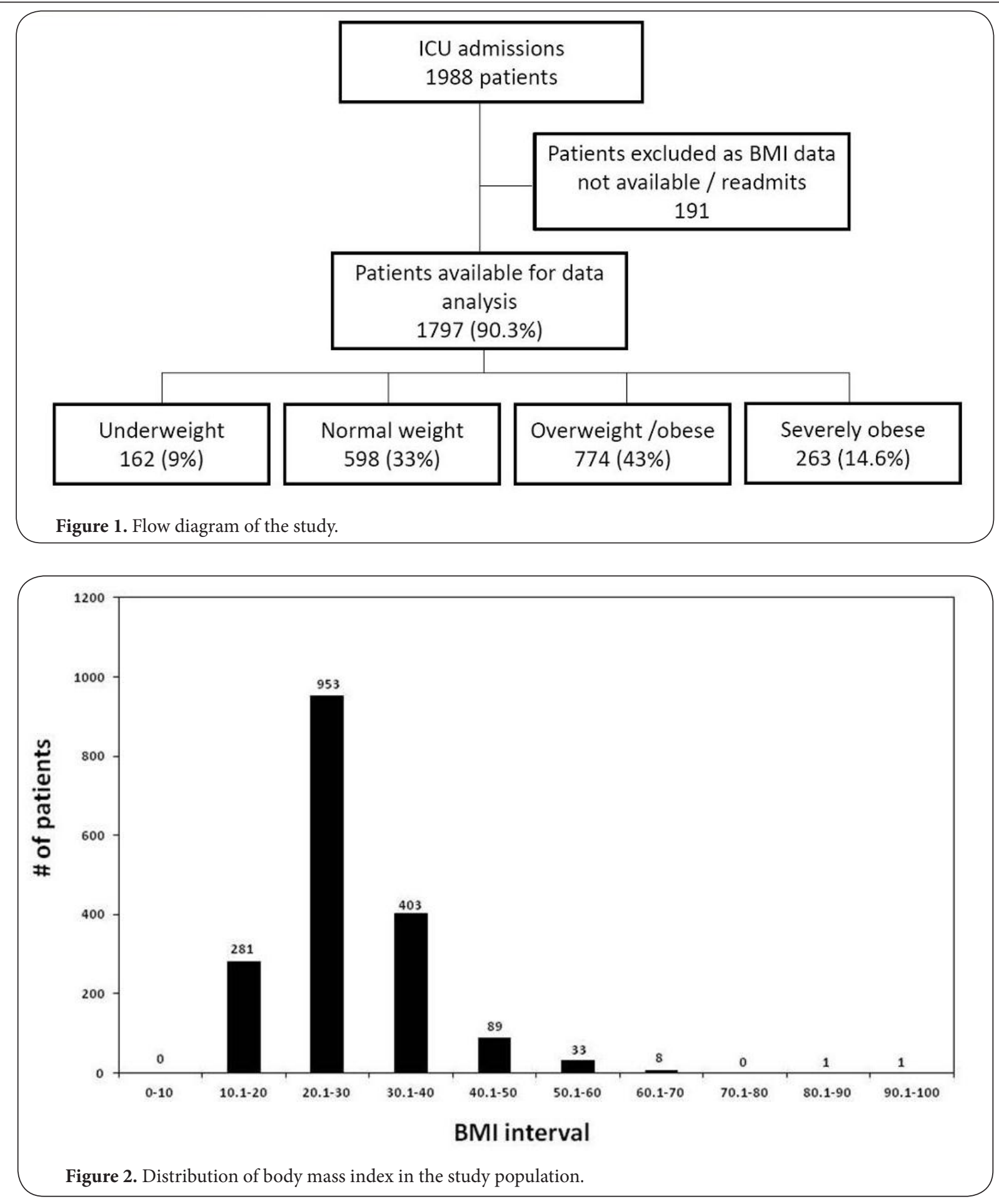

compared with $4.1 \pm 3.9$ in normal, $p=0.0015$ ) (Table 3 ). Univariate analysis on predictors of mortality is shown in Table 4. Logistic regression revealed association of the following variables with mortality in our population: mean age (OR 1.019), APACHE IV score (OR 1.029), history of cancer (OR 4.261), mechanical ventilation (OR 4.767), RVSP (OR 1.015), albumin levels (OR 0.414,) and history of alcohol use (OR 0.48, 95\% Cl 0.257-0.894), however there was no association of different BMI groups and mortality (Table 5).

\section{Discussion}

We found no association between BMI and mortality in our single center cohort. In addition, BMI had no impact in any of the secondary outcomes in our inner city population.

Reported prevalence for severe obesity and underweight in the ICU is between $6 \%$ to $15 \%$ and $10 \%$ to $16 \%$ respectively 
Venkatram et al. Internal Medicine Inside 2013,

http://www.hoajonline.com/journals/pdf/2052-6954-1-1.pdf

doi: $10.7243 / 2052-6954-1-1$

Table 1. Admission characteristics between different BMI groups.

\begin{tabular}{|c|c|c|c|c|c|}
\hline & $\begin{array}{c}\text { Underweight } \\
\text { BMI } \leq 18.5 \\
n=162\end{array}$ & $\begin{array}{c}\text { Normal } \\
\text { BMI } 18.5-24.9 \\
\mathrm{n}=598\end{array}$ & $\begin{array}{c}\text { Overweight /Obese } \\
\text { BMI 25- } 34.9 \\
\text { n=774 }\end{array}$ & $\begin{array}{c}\text { Severe Obesity } \\
\text { BMI } \geq 35 \\
n=263\end{array}$ & $\mathbf{P}$ \\
\hline Male Gender n (\%) & $90(55.6 \%)$ & $324(54.2 \%)$ & $356(47.1 \%)$ & $85(32.3 \%)$ & $<0.0001$ \\
\hline Age, $y($ mean \pm SD $)$ & $56.9 \pm 16.0$ & $56.7 \pm 18.5$ & $57.3 \pm 17.6$ & $55.7 \pm 16.8$ & 0.65 \\
\hline APACHE IV $($ mean \pm SD) & $77.9 \pm 30.7$ & $71.6 \pm 31.8$ & $67.3 \pm 33$ & $65.1 \pm 31.9$ & $<0.0001$ \\
\hline Tobacco use $\mathbf{n}(\%)$ & $59(36.4 \%)$ & $211(35.3 \%)$ & $210(27.8 \%)$ & $78(30 \%)$ & 0.01 \\
\hline Alcohol use n (\%) & $33(20.4 \%)$ & $125(20.9 \%)$ & $151(20 \%)$ & $35(13.3 \%)$ & 0.06 \\
\hline Drug use n (\%) & $40(24.7 \%)$ & $129(21.6 \%)$ & $119(15.7 \%)$ & $41(15.6 \%)$ & 0.004 \\
\hline Hypertension n (\%) & $61(37.7 \%)$ & $295(49.3 \%)$ & $444(58.7 \%)$ & $160(60.8 \%)$ & $<0.0001$ \\
\hline Diabetes n (\%) & $30(18.5 \%)$ & $148(24.8 \%)$ & $287(38 \%)$ & $100(38 \%)$ & $<0.0001$ \\
\hline HIV n (\%) & $61(37.7 \%)$ & $153(25.6 \%)$ & $132(17.5 \%)$ & $31(11.8 \%)$ & $<0.0001$ \\
\hline ESRD n (\%) & $11(6.8 \%)$ & 47 (7.9\%) & $46(6.1 \%)$ & $15(5.7 \%)$ & 0.54 \\
\hline Cancer n (\%) & $22(13.6 \%)$ & $48(8 \%)$ & $64(6 \%)$ & $15(6 \%)$ & 0.006 \\
\hline OSA n (\%) & 0 & 0 & $5(0.66 \%)$ & $18(6.8 \%)$ & $\mathrm{n} / \mathrm{a}$ \\
\hline INR $($ mean \pm SD) & $1.2 \pm 0.6$ & $1.3 \pm 1.2$ & $1.4 \pm 1.3$ & $1.3 \pm 0.9$ & 0.37 \\
\hline Hematocrit $($ mean \pm SD) & $30.9 \pm 8.7$ & $31.4 \pm 8.4$ & $32.9 \pm 7.6$ & $33 \pm 7.8$ & 0.0005 \\
\hline Creatinine $($ mean $\pm \mathrm{SD})$ & $2.3 \pm 2.5$ & $2.2 \pm 2.8$ & $1.9 \pm 2.3$ & $2.2 \pm 3.6$ & 0.09 \\
\hline Albumin $($ mean \pm SD) & $2.9 \pm 0.8$ & $3.1 \pm 0.8$ & $3.1 \pm 0.9$ & $3.2 \pm 0.8$ & 0.003 \\
\hline SGPT $($ mean \pm SD) & $54.5 \pm 99.9$ & $57.9 \pm 255.0$ & $50.2 \pm 168$ & $45.4 \pm 111.4$ & 0.8 \\
\hline SGOT $($ mean \pm SD) & $106.9 \pm 399.3$ & $83.2 \pm 242.1$ & $99.8 \pm 422.1$ & $72.5 \pm 252.4$ & 0.6 \\
\hline ECHO performed & $96(59 \%)$ & $386(64 \%)$ & $465(60 \%)$ & $193(73 \%)$ & - \\
\hline $\operatorname{RVSP}($ mean \pm SD) & $40.2 \pm 15.5$ & $41.5 \pm 16.6$ & $39.3 \pm 13.5$ & $41.1 \pm 23.1$ & 0.4 \\
\hline $\mathrm{EF}($ mean $\pm \mathrm{SD})$ & $57.8 \pm 15$ & $58.5 \pm 15.6$ & $61.4 \pm 13.2$ & $60.8 \pm 15.7$ & 0.01 \\
\hline
\end{tabular}

Table 2. Primary outcomes between different BMI groups.

\begin{tabular}{|c|c|c|c|c|}
\hline & $\begin{array}{l}\text { Non survivors } \\
n=425(\%)\end{array}$ & $\begin{array}{c}\text { Survivors } \\
\mathrm{n}=1372(\%)\end{array}$ & $\mathbf{P}$ & $\begin{array}{c}\text { Odds Ratio } \\
(95 \% \mathrm{CI})\end{array}$ \\
\hline $\begin{array}{l}\text { Underweight } \\
\mathrm{BMI} \leq 18.4, \mathrm{n}=162\end{array}$ & $42(26)$ & $120(74)$ & 0.28 & $1.2(0.8-1.9)$ \\
\hline $\begin{array}{l}\text { Normal } \\
\text { BMI 18.5-24.9, } \\
n=598\end{array}$ & $131(22)$ & 467 (78) & - & - \\
\hline $\begin{array}{l}\text { Overweight/Obese } \\
\text { BMI 25-34.9, } \\
\text { n=774 }\end{array}$ & $181(23)$ & $593(77)$ & 0.5 & $1.1(0.8-1.4)$ \\
\hline $\begin{array}{l}\text { Severe Obesity } \\
B M I \geq 35, n=263\end{array}$ & $71(27)$ & $192(73)$ & 0.1 & $1.3(0.9-1.8)$ \\
\hline
\end{tabular}

$[\mathbf{2 7}, \mathbf{2 8}]$. In our population, we found higher prevalence of obesity and morbid obesity and lower prevalence of underweight patients when compared with other reports $[11,21,28$ and 29]. In agreement with the findings of Martino et al., [29], we found an association between BMI categories and the increased requirement for MV and prolonged ICU stay. Our finding that overweight/obese and severely obese patients were more often to be female when compared with underweight and normal weight patients has been rarely reported for ICU populations [28].

There is evidence that social and demographic factors contributes to obesity. These complex and dynamic "sociodemographic factors" include race/ethnicity, gender, socioeconomic status, psychosocial factors, neighborhood characteristics and safety [30-33]. NHANES data reported that prevalence of obesity among non-Hispanic black males was $38.8 \%$, compared to $36.6 \%$ among Mexican Americans and $36.2 \%$ for non-Hispanic whites. When examined by gender, female non-Hispanic African Americans were more likely to be overweight (58.5\%) compared to Mexican Americans (44.9\%) and non-Hispanic white (32.2\%) [33]. Socio economic status is an additional cause for obesity as evidenced by increased association of obesity in the lower socio economic class [32]. Other interesting associations for obesity include physical inactivity due to building environments and lack of space seen in low-income public housing [34]. Additionally concerns about safety in neighborhoods may influence willingness for physical activity [35-37].

Our hospital serves the low income inner-city population, mainly African Americans and Hispanic community with a lower social economic status. We conclude that the higher incidence of obesity seen in our study most probably reflects the socio-demographic factors that are unique in our catchment population.

Obesity and severe obesity have been found to be a protective factor for mortality compared to patients with normal BMI in various disease processes including cardiovascular diseases, congestive heart failure, ESRD and 
Venkatram et al. Internal Medicine Inside 2013,

http://www.hoajonline.com/journals/pdf/2052-6954-1-1.pdf

Table 3. Secondary outcomes between different BMI groups.

\begin{tabular}{lcccc}
\hline & $\begin{array}{c}\text { Underweight } \\
\text { BMI } \leq \mathbf{1 8 . 5}, \mathbf{n}=\mathbf{1 6 2}\end{array}$ & $\begin{array}{c}\text { Normal } \\
\text { BMI 18.5-24.9, } \mathbf{n = 5 9 8}\end{array}$ & $\begin{array}{c}\text { Overweight /Obese } \\
\text { BMI 25- 34.9, } \mathbf{n}=\mathbf{7 7 4}\end{array}$ & $\begin{array}{c}\text { Severe Obesity } \\
\mathbf{B M I} \geq \mathbf{3 5}, \mathbf{n}=\mathbf{2 6 3}\end{array}$ \\
\hline $\begin{array}{l}\text { Patients on Mechanical venti- } \\
\text { lation n (\%) }\end{array}$ & $61(38.4)$ & $169(29.7)$ & $260(36)$ & $105(41)$ \\
Tracheotomy n (\%) & $8(11.1)$ & $61(10.2)$ & $75(9.9)$ & $24(9.1)$ \\
ICU LOS (mean \pm SD) & $4.3 \pm 3.9$ & $4.1 \pm 3.9$ & $4.4 \pm 4.5$ & 0.006 \\
Hospital LOS (mean \pm SD) & $17.7 \pm 15.5$ & $16.9 \pm 23.2$ & $15 \pm 17.8$ & $5.3 \pm 5.1$ \\
Ventilator Days (mean \pm SD) & $9.2 \pm 14.8$ & $9.9 \pm 15.2$ & $11.1 \pm 19.7$ & $17 \pm 19.6$ \\
\hline
\end{tabular}

Table 4. Univariate indicators of mortality.

\begin{tabular}{|c|c|c|c|}
\hline Variable & $\begin{array}{c}\text { Non survivors } \\
\mathbf{n}=425\end{array}$ & $\begin{array}{c}\text { Survivors } \\
n=1372\end{array}$ & $P$ value \\
\hline Male Gender $(n=855) \%$ & 51 & 47 & 0.16 \\
\hline Age, Mean (SD) & $63.3(15.8)$ & $54.8(17.8)$ & $<0.0001$ \\
\hline APACHE IV, Mean (SD) & $99.2(34.9)$ & $60.1(25.2)$ & $<0.0001$ \\
\hline Tobacco use n (\%) & $96(22.8 \%)$ & $462(34 \%)$ & $<0.0001$ \\
\hline Alcohol use n (\%) & $45(10.7 \%)$ & $299(22 \%)$ & $<0.0001$ \\
\hline Drug use $n(\%)$ & $63(15 \%)$ & $266(20 \%)$ & 0.03 \\
\hline Hypertension n (\%) & $235(56 \%)$ & $725(53 \%)$ & 0.38 \\
\hline Diabetes n (\%) & $128(30 \%)$ & $437(32 \%)$ & 0.5 \\
\hline HIV n (\%) & $119(28 \%)$ & $258(19 \%)$ & $<0.0001$ \\
\hline ESRD n (\%) & $28(7 \%)$ & $91(7 \%)$ & 0.97 \\
\hline Cancer n (\%) & $51(12 \%)$ & $80(6 \%)$ & $<0.0001$ \\
\hline OSA n (\%) & $3(0.7 \%)$ & $20(1.5 \%)$ & 0.32 \\
\hline $\operatorname{INR}($ mean $\pm S D)$ & $1.6 \pm 1.4$ & $1.2 \pm 1.0$ & $<0.0001$ \\
\hline Hematocrit (mean \pm SD) $\%$ & $29.1 \pm 7.3$ & $33.2 \pm 8.0$ & $<0.0001$ \\
\hline Creatinine (mean $\pm \mathrm{SD}) \mathrm{mg} / \mathrm{dl}$ & $2.5 \pm 2.7$ & $2.0 \pm 2.7$ & $<0.0001$ \\
\hline Albumin $($ mean $\pm S D) g / d l$ & $2.4 \pm 0.8$ & $3.3 \pm 0.8$ & $<0.0001$ \\
\hline SGPT $($ mean \pm SD) unit $/ 1$ & $74 \pm 207.4$ & $45.8 \pm 185.5$ & 0.003 \\
\hline SGOT (mean \pm SD) unit $/ 1$ & $161.2 \pm 578.6$ & $69 \pm 225.1$ & $<0.0001$ \\
\hline RVSP $($ mean \pm SD) $\mathrm{mmHg}$ & $43.6 \pm 19.4$ & $39.3 \pm 15.3$ & 0.0007 \\
\hline $\mathrm{EF}($ mean $\pm \mathrm{SD})$ & $58.3 \pm 16.8$ & $60.7 \pm 13.7$ & 0.12 \\
\hline Intubated n (\%) & $294(74.6 \%)$ & $301(22.9 \%)$ & $<0.0001$ \\
\hline Ventilator days (mean \pm SD) & $12.4 \pm 19.9$ & $9.3 \pm 15.6$ & 0.03 \\
\hline Tracheotomy n (\%) & $49(11.7 \%)$ & $129(9.5 \%)$ & 0.19 \\
\hline ICU LOS $($ mean \pm SD $)$ & $6.2 \pm 6.1$ & $3.9 \pm 3.5$ & $<0.0001$ \\
\hline Hospital LOS (mean \pm SD) & $21.9 \pm 23.6$ & $14.4 \pm 18.2$ & $<0.0001$ \\
\hline
\end{tabular}

HIV/AIDS $[\mathbf{2 2}, \mathbf{3 8}]$. The protective role of obesity have been postulated to be due to factors like increased nutritional reserve, younger age, role of adipose tissue and higher levels of immune modulating anti-inflammatory adipokines [39-42]. There are few studies addressing outcomes for the underweight patient in the ICU. A large study, not restricted to ICU patients that included 1.46 million white (nonHispanic) adults and 160,087 deaths showed that overweight,
Table 5. Multivariate logistic regression analysis for mortality.

\begin{tabular}{lc}
\hline Variables & Odds Ratio (confidence interval) \\
\hline Underweight versus Normal BMI & $1.162(0.576-2.343)$ \\
Overweight/Obese versus Normal BMI & $1.047(0.627-1.751)$ \\
Severe Obesity versus Normal BMI & $1.239(0.642-2.391)$ \\
Cancer & $4.261(2.083-8.716)$ \\
History of alcohol use & $0.480(0.257-0.894)$ \\
Mechanical ventilation & $4.767(2.930-7.755)$ \\
Apache IV & $1.029(1.021-1.038)$ \\
Age & $1.019(1.005-1.033)$ \\
Albumin & $0.414(0.313-0.549)$ \\
RVSP ${ }^{* 25}$ mmHg & $1.015(1.003-1.028)$ \\
ICU LOS & \\
\hline$*$ Right & $1.051(1.005-1.099)$ \\
\hline
\end{tabular}

* Right ventricular systolic pressure, ${ }^{* *}$ MICU Length of stay

obesity and possibly underweight were associated with an increased all-cause mortality [43]. Finkielman et al., [44] reported that a $\mathrm{BMI}<18.5$ was associated with increased mortality in both, post-operative $(\mathrm{OR}=2.14,95 \% \mathrm{Cl}, 1.39$ to 3.28$)$ and non-operative ( $\mathrm{OR}=1.51,95 \% \mathrm{Cl}, 1.13$ to 2.01$)$ patients. In addition the LOS was increased in post-operative patients with low BMI. Other studies report no correlation between low BMI and mortality or LOS in the ICU $[27,28]$. In our study, $9 \%$ of our patients were underweight and our results support published data regarding no effect of $\mathrm{BMI}$ in outcomes.

The impact of BMIs in the requirement for MV and the outcome for those patients are mixed with most of the reports addressing the obese population [11,19,45-49]. Pulmonary physiological changes related to elevated BMI includes a decreased lung compliance with a lower total lung capacity, functional residual capacity and residual volume and an increased airway resistance. These changes can lead to atelectasis and hypoxemia. Clinically this will translate in a higher risk for aspiration and difficult airway [50]. Some studies suggest that critically ill patients with elevated BMls would have an increased need for MV and prolonged mechanical ventilation [11,29,48 and 49]. Other studies have shown that BMI have no impact on days of MV, however, a difficult airway and a higher incidence of post extubation stridor have been reported in the morbidly obese patients $[\mathbf{4 5 , 4 6 , 5 1 ]}$. A lower BMI was associated with 
increased mortality in mechanically ventilated patients with acute respiratory distress syndrome [47]. The effect of low $\mathrm{BMI}$ on patient requiring $\mathrm{MV}$ is unclear, but it have been suggested that a low BMI could be associated with increased malnutrition and muscle weakness leading to prolonged MV. In our study the extremes of BMI groups were more likely to require $\mathrm{MV}$ compared to normal BMI. However, days on mechanical ventilation and tracheotomy rates were similar between $\mathrm{BMI}$ groups.

Similar to inconsistent relationship mortality and MV the data for ICU and hospital LOS varies as well. Some studies reports a higher ICU and hospital LOS across all BMI groups $[20,23]$ while others reports no correlation [17]. In our study although the Hospital LOS were similar between BMI groups, The ICU LOS was higher in severely obese patients. We could speculate that the ICU LOS in severely obese patients in our institution is related to intensivist practice. Most of the severely obese patients require additional care and increase monitoring; it is not uncommon that patients are kept longer in the ICU until they are deemed very stable to be transfer to floor at which time the discharge period is shorter.

In our study there was no association between BMI and pulmonary hypertension in critically ill patients; however the presence of pulmonary hypertension as assessed by elevated RVSP, was a predictor of mortality. The association of BMI with pulmonary HTN remains controversial with some studies suggesting an association $[\mathbf{5 2}, \mathbf{5 3}]$ while other did not report this association [54]. Common causes of pulmonary hypertension in the critically ill include chronic cardiac or pulmonary diseases or acute pulmonary hypertension due to critical illness like acute respiratory distress syndrome, sepsis or pulmonary embolism. Despite right sided heart catheterization been the accepted standard approach in determining pulmonary artery pressure [55], Doppler echocardiography is widely used in the ICU to screen for pulmonary HTN. Estimates of pulmonary artery systolic pressures by Doppler echocardiography are usually inaccurate in patients with pulmonary hypertension and should not be relied solely to make the diagnosis [56]. We admit that these associations may be simply a detection bias as patients without echocardiograms (36\%) during the hospitalization were assumed to have normal echocardiograms.

Our work validate the association of mortality with a low serum albumin $[\mathbf{5 7}, \mathbf{5 8}]$ and admission APACHE IV scores [59] irrespective of BMI groups. There is no severity of illness assessment tool specifically designed for the obese or underweight, and any existing assessment tool, including APACHE IV, may not be accurate to reflect mortality risk in extremely obese patients due to "hidden" factors not accounted for in the assessment. The inverse association of alcohol use and mortality may be explained by reporting bias.

The associations between extremes of hemoglobin concentration and mortality in acute stroke have been reported, with some studies showing an association between mortality and higher hematocrit in patient with stroke $[60,61]$. The association between low hematocrit and mortality in acute coronary syndromes are well established [62]. In our study there was a linear correlation between BMI categories and admission hematocrit. Patients with higher BMI had a higher hematocrit when compared to patients with a lower BMI. Univariate analysis revealed that patients with lower hematocrit had a higher mortality compared to patients with lower hematocrit. However this association was not validated by multivariate analysis and therefore our study found no association between admission hematocrit and mortality.

There are several strengths in our study. First, availability of admission height, weight and BMI data in majority of our patients. Second, this study describes an inner city population with a high prevalence of obesity and co morbid conditions specially HIV infection. Third, the comparison of outcomes across all BMI groups. Fourth, in our ICU, there are weaning and sedation practice protocols which decreases individual variations and effect in weaning and LOS on MV.

Limitations of our study include all limitations of retrospective observational studies and single center study. In addition, we did not account for recent weight gain or loss prior to hospital admission and there are no measures of waist-to-thigh ratio in both gender and waist-to-hip ratio in women which have been were positively associated with mortality in middle-aged adults [52]. Volume resuscitation in the ED in patients with severe sepsis and septic shock would have resulted in pseudo obesity in a small group of patients, however we feel this effect would affect all BMI groups. We did not adjust for the co morbid conditions that could have masked a true association with mortality.

\section{Conclusion}

In conclusion, our study demonstrates that there is no association of BMI with mortality or any other outcomes in critically ill inner city population. Severely obese patients have a longer ICU LOS, but a similar hospital LOS.

\section{Key messages}

There is no association of BMI with mortality in critically ill patients in an inner city population. ICU length of stay is longer for the severely obese patients. Prevalence of obesity and severe obesity is higher in our inner city population.

\author{
Abbreviations \\ NHANES: National Health and Nutrition Examination Survey \\ BMI: Body mass index \\ ICU: Intensive care unit \\ LOS: Length of stay \\ MV: Mechanical ventilation \\ HTN: Hypertension \\ DM: Diabetes mellitus \\ HIV: Human immunodeficiency virus
}


Venkatram et al. Internal Medicine Inside 2013,

http://www.hoajonline.com/journals/pdf/2052-6954-1-1.pdf

ESRD: End stage renal disease

OSA: Obstructive sleep apnea

APACHE: Acute physiology and chronic health evaluation

HCT: Hematocrit

SGOT: Glutamic oxaloacetic transaminase

SGPT: Glutamic pyruvic transaminase

INR: International normalized ratio

RVSP: Right ventricular systolic pressure

EF: Ejection fraction

SD: Standard deviations

\section{Competing interests}

The authors declare that they have no competing interests.

\section{Authors' contributions}

SV conceived the study, and participated in the analysis of data and revising the manuscript critically for important intellectual content. VR participated in the acquisition and interpretation of data and drafting the manuscript. MA participated in the acquisition and analysis of data and drafting the manuscript. GDF participated in the design of the study and revising the manuscript critically for important intellectual content. All authors read and approved the final manuscript.

\section{Publication history}

Editor: Francesca Pistoia, University of L'Aquila, Italy.

Received: 24-Mar-2013 Revised: 19-Apr-2013

Accepted: 22-Apr-2013 Published: 01-May-2013

\section{References}

1. Flegal KM, Carroll MD, Ogden $C L$ and Curtin LR: Prevalence and trends in obesity among US adults, 1999-2008. JAMA 2010, 303:23541. | Article | PubMed

2. Katzmarzyk PT, Janssen I and Ardern Cl: Physical inactivity, excess adiposity and premature mortality. Obes Rev 2003, 4:257-90. | Article | PubMed

3. McGee DL: Body mass index and mortality: a meta-analysis based on person-level data from twenty-six observational studies. Ann Epidemiol 2005, 15:87-97. | Article | PubMed

4. Adams KF, Schatzkin A, Harris TB, Kipnis V, Mouw T, Ballard-Barbash R, Hollenbeck $A$ and Leitzmann MF: Overweight, obesity, and mortality in a large prospective cohort of persons $\mathbf{5 0}$ to $\mathbf{7 1}$ years old. $N$ Engl J Med 2006, 355:763-78. | Article | PubMed

5. Yan LL, Daviglus ML, Liu K, Stamler J, Wang R, Pirzada A, Garside DB Dyer AR, Van Horn L, Liao Y, Fries JF and Greenland P: Midlife body mass index and hospitalization and mortality in older age. JAMA 2006, 295:190-8. | Article | PubMed

6. Galal W, van Domburg RT, Feringa $\mathrm{HH}$, Schouten O, Elhendy A, Bax JJ, Awara AM, Klein J and Poldermans D: Relation of body mass index to outcome in patients with known or suspected coronary artery disease. Am J Cardiol 2007, 99:1485-90. | Article | PubMed

7. Galal W, van Gestel YR, Hoeks SE, Sin DD, Winkel TA, Bax JJ, Verhagen $H$, Awara AM, Klein J, van Domburg RT and Poldermans D: The obesity paradox in patients with peripheral arterial disease. Chest 2008, 134:925-30. | Article | PubMed

8. Troiano RP, Frongillo EA, Jr., Sobal J and Levitsky DA: The relationship between body weight and mortality: a quantitative analysis of combined information from existing studies. Int J Obes Relat Metab Disord 1996, 20:63-75. | Article | PubMed

9. Physical status: the use and interpretation of anthropometry. Report of a WHO Expert Committee. Technical Report Series No. 854. 1995, 854:1- 452. | Website

10. Manson JE, Stampfer MJ, Hennekens CH and Willett WC: Body weight and longevity. A reassessment. JAMA 1987, 257:353-8. | Article | PubMed

11. Akinnusi ME, Pineda LA and EI Solh AA: Effect of obesity on intensive care morbidity and mortality: a meta-analysis. Crit Care Med 2008, 36:151-8. | Article | PubMed

12. Alban RF, Lyass S, Margulies DR and Shabot MM: Obesity does not affect mortality after trauma. Am Surg 2006, 72:966-9. | Article | PubMed

13. Aldawood A, Arabi Y and Dabbagh O: Association of obesity with increased mortality in the critically ill patient. Anaesth Intensive Care 2006, 34:629-33. | Article | PubMed

14. Nasraway SA, Jr., Albert M, Donnelly AM, Ruthazer R, Shikora SA and Saltzman E: Morbid obesity is an independent determinant of death among surgical critically ill patients. Crit Care Med 2006, 34:964-70; quiz 971. | Article | PubMed

15. Neville AL, Brown CV, Weng J, Demetriades D and Velmahos GC: Obesity is an independent risk factor of mortality in severely injured blunt trauma patients. Arch Surg 2004, 139:983-7. | Article I PubMed

16. O’Brien JM, Jr., Phillips GS, Ali NA, Lucarelli M, Marsh CB and Lemeshow $\mathrm{S}$ : Body mass index is independently associated with hospital mortality in mechanically ventilated adults with acute lung injury. Crit Care Med 2006, 34:738-44. | Article | PubMed Abstract | PubMed Full Text

17. Hogue CW, Jr., Stearns JD, Colantuoni E, Robinson KA, Stierer T, Mitter N, Pronovost PJ and Needham DM: The impact of obesity on outcomes after critical illness: a meta-analysis. Intensive Care Med 2009, 35:1152-70. | Article | PubMed

18. Dossett LA, Heffernan D, Lightfoot M, Collier B, Diaz JJ, Sawyer RG and May AK: Obesity and pulmonary complications in critically injured adults. Chest 2008, 134:974-80. | Article | PubMed Abstract | PubMed Full Text

19. Morris AE, Stapleton RD, Rubenfeld GD, Hudson LD, Caldwell E and Steinberg KP: The association between body mass index and clinical outcomes in acute lung injury. Chest 2007, 131:342-8. | Article | PubMed

20. Oliveros $\mathrm{H}$ and Villamor $\mathrm{E}$ : Obesity and mortality in critically ill adults: a systematic review and meta-analysis. Obesity (Silver Spring) 2008, 16:515-21. | Article | PubMed

21. Sakr Y, Madl C, Filipescu D, Moreno R, Groeneveld J, Artigas A, Reinhart $\mathrm{K}$ and Vincent JL: Obesity is associated with increased morbidity but not mortality in critically ill patients. Intensive Care Med 2008, 34:1999-2009. | Article | PubMed

22. Kalantar-Zadeh K, Horwich TB, Oreopoulos A, Kovesdy CP, Younessi $\mathrm{H}$, Anker SD and Morley JE: Risk factor paradox in wasting diseases. Curr Opin Clin Nutr Metab Care 2007, 10:433-42. | Article I PubMed

23. Marik PE, Doyle $H$, Varon J. Is obesity protective during critical illness? An analysis of a national ICU database. Crit Care Shock 2003; 6:156-162. I Pdf

24. Karpati A, Kerker B, Mostashari F: Health Disparities in New York City. New York: New York City Department of Health and Mental Hygiene, 2004. I Pdf

25. World Health Organization. (1997) Obesity: preventing and managing the global epidemic of obesity. Report of the WHO Consultation of Obesity. Geneva, Switzerland. June 3-5. | Website

26. Clinical Guidelines on the Identification, Evaluation, and Treatment of Overweight and Obesity in Adults--The Evidence Report. National Institutes of Health. Obes Res 1998, 6 Suppl 2:51S-209S. | PubMed

27. Tremblay A and Bandi V: Impact of body mass index on outcomes following critical care. Chest 2003, 123:1202-7. | Article | PubMed

28. Ray DE, Matchett SC, Baker K, Wasser T and Young MJ: The effect of body mass index on patient outcomes in a medical ICU. Chest 2005, 127:2125-31. | Article | PubMed

29. Martino JL, Stapleton RD, Wang M, Day AG, Cahill NE, Dixon AE, Suratt BT and Heyland DK: Extreme obesity and outcomes in critically ill patients. Chest 2011, 140:1198-206. | Article | PubMed Abstract | PubMed Full Text

30. Wang $\mathrm{Y}$ and Beydoun MA: The obesity epidemic in the United States--gender, age, socioeconomic, racial/ethnic, and geographic characteristics: a systematic review and meta-regression analysis. Epidemiol Rev 2007, 29:6-28. | Article | PubMed

31. Paeratakul S, Lovejoy JC, Ryan DH and Bray GA: The relation of gender, race and socioeconomic status to obesity and obesity comorbidities in a sample of US adults. Int J Obes Relat Metab Disord 2002, 26:1205-10. | Article | PubMed

32. Sobal J and Stunkard AJ: Socioeconomic status and obesity: a review of the literature. Psychol Bull 1989, 105:260-75. | Article | PubMed

33. Fryar Ch, Carroll M, Ogden C. NCHS Health E-Stat; Prevalence of Overweight, Obesity, and Extreme Obesity Among Adults: United 
Venkatram et al. Internal Medicine Inside 2013,

http://www.hoajonline.com/journals/pdf/2052-6954-1-1.pdf

doi: $10.7243 / 2052-6954-1-1$

States, Trends 1960-1962 Through 2009-2010. Division of Health and Nutrition Examination Surveys. September 2012. | Website

34. Heinrich KM, Lee RE, Suminski RR, Regan GR, Reese-Smith JY, Howard $\mathrm{HH}$, Haddock CK, Poston WS and Ahluwalia JS: Associations between the built environment and physical activity in public housing residents. Int J Behav Nutr Phys Act 2007, 4:56. | Article | PubMed Abstract | PubMed Full Text

35. Bennett GG, McNeill LH, Wolin KY, Duncan DT, Puleo E and Emmons KM: Safe to walk? Neighborhood safety and physical activity among public housing residents. PLOS Med 2007, 4:1599-606. | Article | PubMed Abstract | PubMed Full Text

36. Duncan DT, Johnson RM, Molnar BE and Azrael D: Association between neighborhood safety and overweight status among urban adolescents. BMC Public Health 2009, 9:289. | Article | PubMed Abstract | PubMed Full Text

37. Fox AM, Mann DM, Ramos MA, Kleinman LC and Horowitz CR: Barriers to physical activity in East harlem, new york. J Obes 2012, 2012:719140. | Article | PubMed Abstract | PubMed Full Text

38. Habbu A, Lakkis NM and Dokainish $\mathrm{H}$ : The obesity paradox: fact or fiction? Am J Cardiol 2006, 98:944-8. | Article | PubMed

39. Ahima RS, Flier JS: Adipose tissue as an endocrine organ. Trends Endocrinol Metab 2000, 11:327-32. | Article

40. Wajchenberg BL: Subcutaneous and visceral adipose tissue: their relation to the metabolic syndrome. Endocr Rev 2000, 21:697-738. Article | PubMed

41. Rice TW: Obesity in acute lung injury: The "weight" is over. Chest 2007, 131:333-4. | Article | PubMed

42. Bornstein SR, Licinio J, Tauchnitz R, Engelmann L, Negrao AB, Gold P and Chrousos GP: Plasma leptin levels are increased in survivors of acute sepsis: associated loss of diurnal rhythm, in cortisol and leptin secretion. J Clin Endocrinol Metab 1998, 83:280-3. | Article | PubMed

43. Berrington de Gonzalez A, Hartge P, Cerhan JR, Flint AJ, Hannan L, Maclnnis RJ, Moore SC, Tobias GS, Anton-Culver H, Freeman LB, Beeson WL, Clipp SL, English DR, Folsom AR, Freedman DM, Giles G, Hakansson N, Henderson KD, Hoffman-Bolton J, Hoppin JA, Koenig KL, Lee IM, Linet MS, Park Y, Pocobelli G, Schatzkin A, Sesso HD, Weiderpass E, Willcox BJ, Wolk A, Zeleniuch-Jacquotte A, Willett WC and Thun MJ: Body-mass index and mortality among 1.46 million white adults. N Engl J Med 2010, 363:2211-9. | Article | PubMed Abstract | PubMed Full Text

44. Finkielman JD, Gajic $O$ and Afessa B: Underweight is independently associated with mortality in post-operative and non-operative patients admitted to the intensive care unit: a retrospective study. BMC Emerg Med 2004, 4:3. | Article | PubMed Abstract | PubMed Full Text

45. Anzueto A, Frutos-Vivar F, Esteban A, Bensalami N, Marks D, Raymondos K, Apezteguia C, Arabi Y, Hurtado J, Gonzalez M, Tomicic $\mathrm{V}$, Abroug F, Elizalde J, Cakar N, Pelosi P and Ferguson ND: Influence of body mass index on outcome of the mechanically ventilated patients. Thorax 2011, 66:66-73. | Article | PubMed

46. Frat JP, Gissot V, Ragot S, Desachy A, Runge I, Lebert C and Robert R: Impact of obesity in mechanically ventilated patients: a prospective study. Intensive Care Med 2008, 34:1991-8. | Article | PubMed

47. O'Brien JM, Jr., Welsh CH, Fish RH, Ancukiewicz M and Kramer AM: Excess body weight is not independently associated with outcome in mechanically ventilated patients with acute lung injury. Ann Intern Med 2004, 140:338-45. | Article | PubMed

48. Brown CV, Rhee P, Neville AL, Sangthong B, Salim A and Demetriades D: Obesity and traumatic brain injury. J Trauma 2006, 61:572-6. | Article I PubMed

49. El-Solh A, Sikka P, Bozkanat E, Jaafar W and Davies J: Morbid obesity in the medical ICU. Chest 2001, 120:1989-97. | Article | PubMed

50. Malhotra A and Hillman D: Obesity and the lung: 3. Obesity, respiration and intensive care. Thorax 2008, 63:925-31. | Article | PubMed Abstract | PubMed Full Text

51. Byrnes MC, McDaniel MD, Moore MB, Helmer SD and Smith RS: The effect of obesity on outcomes among injured patients. J Trauma 2005, 58:232-7. | Article | PubMed Abstract | PubMed Full Text

52. McQuillan BM, Picard MH, Leavitt M and Weyman AE: Clinical correlates and reference intervals for pulmonary artery systolic pressure among echocardiographically normal subjects. Circulation 2001, 104:2797-802. | Article | PubMed

53. Weyman AE, Davidoff R, Gardin J, Ryan T, St John Sutton M and Weissman NJ: Echocardiographic evaluation of pulmonary artery pressure with clinical correlates in predominantly obese adults. $J \mathrm{Am}$ Soc Echocardiogr 2002, 15:454-62. | Article | PubMed

54. Milani RV, Lavie CJ and Rubiano A: Clinical correlates and reference intervals for pulmonary artery systolic pressure among echocardiographically normal subjects. Circulation 2002, 106:e19; author reply e19. | Article | PubMed

55. McLaughlin VV, Archer SL, Badesch DB, Barst RJ, Farber HW, Lindner $J R$, Mathier MA, McGoon MD, Park MH, Rosenson RS, Rubin LJ, Tapson VF, Varga J, Harrington RA, Anderson JL, Bates ER, Bridges $C R$, Eisenberg MJ, Ferrari VA, Grines CL, Hlatky MA, Jacobs AK, Kaul S, Lichtenberg RC, Moliterno DJ, Mukherjee D, Pohost GM, Schofield RS, Shubrooks SJ, Stein JH, Tracy CM, Weitz HH and Wesley DJ: ACCF/ AHA 2009 expert consensus document on pulmonary hypertension: a report of the American College of Cardiology Foundation Task Force on Expert Consensus Documents and the American Heart Association: developed in collaboration with the American College of Chest Physicians, American Thoracic Society, Inc., and the Pulmonary Hypertension Association. Circulation 2009, 119:2250-94. | Article | PubMed

56. Rich JD, Shah SJ, Swamy RS, Kamp A and Rich S: Inaccuracy of Doppler echocardiographic estimates of pulmonary artery pressures in patients with pulmonary hypertension: implications for clinical practice. Chest 2011, 139:988-93. | Article | PubMed

57. Freire AX, Bridges L, Umpierrez GE, Kuhl D and Kitabchi AE: Admission hyperglycemia and other risk factors as predictors of hospital mortality in a medical ICU population. Chest 2005, 128:3109-16. | Article | PubMed

58. Yap FH, Joynt GM, Buckley TA and Wong EL: Association of serum albumin concentration and mortality risk in critically ill patients. Anaesth Intensive Care 2002, 30:202-7. I PubMed

59. Z Zimmerman JE, Kramer AA, McNair DS and Malila FM: Acute Physiology and Chronic Health Evaluation (APACHE) IV: hospital mortality assessment for today's critically ill patients. Crit Care Med 2006, 34:1297-310. | Article | PubMed

60. Tanne D, Molshatzki N, Merzeliak O, Tsabari R, Toashi M and Schwammenthal Y: Anemia status, hemoglobin concentration and outcome after acute stroke: a cohort study. BMC Neurol 2010, 10:22. | Article | PubMed Abstract | PubMed Full Text

61. Sacco S, Marini C, Olivieri L, Pistoia F and Carolei A: Contribution of hematocrit to early mortality after ischemic stroke. Eur Neurol 2007, 58:233-8. | Article | PubMed

62. Sabatine MS, Morrow DA, Giugliano RP, Burton PB, Murphy SA, McCabe $\mathrm{CH}$, Gibson $\mathrm{CM}$ and Braunwald $\mathrm{E}$ : Association of hemoglobin levels with clinical outcomes in acute coronary syndromes. Circulation 2005, 111:2042-9. | Article | PubMed

63. Reis JP, Macera CA, Araneta MR, Lindsay SP, Marshall SJ and Wingard $\mathrm{DL}$ : Comparison of overall obesity and body fat distribution in predicting risk of mortality. Obesity (Silver Spring) 2009, 17:1232-9. | Article | PubMed

Citation:

Venkatram S, Rapaka V, Anwer M and Diaz-Fuentes G: Body mass index have no effect in hospital mortality or intensive care outcomes in an inner city population. Internal Medicine Inside 2013, 1:1. http://dx.doi.org/10.7243/2052-6954-1-1 